
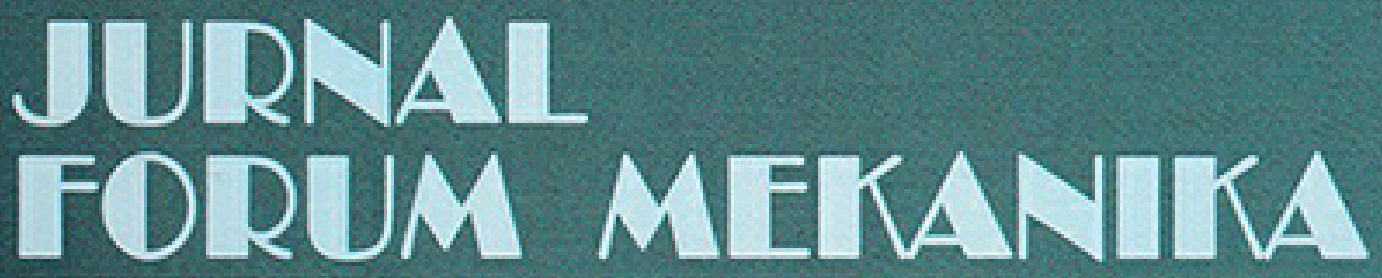

Volume 6 - Nomor 2 November 2017 ISSN : 2356-1491

ANALISIS RUMAH KABEL BAWAH TANAH PADA PROYEK PEKERJAAN JARINGAN UTILITAS SKTT 150 KV PLUMPANG - GAMBIR DYAH PRATIWI KUSUMASTUTI; IRMA SEPRIYANNA

STUDI KOMPARASI ANTARA PRACETAK MASIF DAN FLY SLAB STUDI KASUS: STRUKTUR GEDUNG RUSUNAWA SURAKARTA BUDI WICAKSONO

SISTEM DRAINASE ALIRAN BAWAH TANAH UNTUK DAERAH RAWAN LONGSOR (STUDI KASUS SUB DAS SUNGAI CIKAPUNDUNG, BANDUNG) ENDAH LESTARI

ANALISA STATISTIK DEBIT BANIIR DAN DEBIT ANDALAN SUNGAI KOMERING SUMATERA SELATAN DEVITA MAYASARI

STUDI EKSPERIMENTAL KUAT LENTUR BAJA PROFIL I KOMPAK SIMETRIS GANDA BERDASARKAN RSNI 03-1729-201X

DICKI DIAN PURNAMA; AKHMAD AMINULLAH; MUSLIKH

PENGGUNAAN PASIR LAUT TERHADAP KUAT TEKAN BETON KOTA BENGKULU TOMMYIDUWIN

ANALISA PENGARUH ADMIXTURE TERHADAP ABU TERBANG (FLY ASH) DAN BOTTOM ASH

TRI YUHANAH; NOVIA ADE MANDASARI

ANALISA KINERJA PERSIMPANGAN BERSINYAL PADA PERSIMPANGAN ANGKATAN 66 DAN RUAS JALAN R. SOEKAMTO KOTA PALEMBANG YULES PRAMONA ZULKARNAIN; IRMA INDRIANI 


\title{
SISTEM DRAINASE ALIRAN BAWAH TANAH UNTUK DAERAH RAWAN LONGSOR (STUDI KASUS SUB DAS SUNGAI CIKAPUNDUNG, BANDUNG)
}

\author{
ENDAH LESTARI \\ Jurusan Teknik Sipil, Sekolah Tinggi Teknik - PLN \\ Email: endah.lestari@gmail.com
}

\begin{abstract}
Abstrak
Restorasi Sungai Cikapundung terletak pada sempadan sungai dengan kemiringan lereng yang curam dan berombak-ombak ke barat - timur yang dibentuk dari aliran sungai cikapundung. Umumnya, struktur tanah lereng Das Sungai Cikapundung adalah tanah residual, hasil korosi batu dan deposisi colluvial, yang menyebabkan rentan terhadap longsor. Itu juga terpisah dan mampu menjaga air. Oleh karena itu, kekuatan geser lemah, terutama jika air jenuh. Pada kasus ini longsor selalu terjadi waktu hujan. Secara umum, hal ini disebabkan curah hujan yang tinggi dengan durasi tertentu, sehingga menyebabkan stabilitas lereng terganggu . Penyebab lain adalah sistem drainase yang tidak berfungsi karena itu tertutup oleh beberapa materi dari lereng yang disampaikan oleh air. Oleh karena itu, air menggosok lereng .
\end{abstract}

Kata kunci : longsor, lereng, hujan, infiltrasi, drainase .

\begin{abstract}
Cikapundung River Restoration lies in a river border with a steep sloping slope and waves to the west - east which is formed from the flow of the river cikapundung. Generally, the soil structure of the Cikapundung River Basin slope is residual ground, corrosion stone and colluvial deposition, which caused vulnerable to landslides. It was also separate and able to keep water. Therefore, shear strength is weak, especially if water is saturated. In this case landslides always occur when it rains. In general, this is due to high rainfall with a certain duration, thus causing the stability of the slope is disrupted. Another cause is the non-functioning drainage system because it is covered by some material from the slopes submitted by water. Therefore, the water rubs the slope.
\end{abstract}

Keywords: landslides, slopes, rain, infiltration, drainage.

\section{PENDAHULUAN}

Indonesia terletak pada pertemuan tiga lempeng dunia yaitu lempeng Eurasia, lempeng Pasifik, dan lempeng Australia yang selalu bergerak dan saling menumbuk. Konsekuensi dari tubrukan tersebut adalah terbentuknya jalur gunungapi dan vulkanik di Indonesia. Keberadaan jalur gunung api di wilayah Indonesia menyebabkan beberapa wilayah Indonesia memiliki bentuk lahan pegunungan dan perbukitan yang memiliki lereng yang landai hingga terjal. Kondisi tersebut menyebabkan Indonesia memiliki berbagai potensi bencana seperti letusan gunung api, tsunami, gempabumi, banjir, dan longsor. Bencana tanah longsor merupakan bencana yang setiap tahun terjadi di Indonesia. Intensitas kejadian longsor semakin meningkat memasuki musim penghujan. Selain disebabkan faktor geologis dan geomorfologis Indonesia, perubahan fungsi dan tata guna lahan yang dilakukan manusia membawa pengaruh yang besar sebagai penyebab longsor. Perubahan fungsi lahan tersebut menimbulkan kerusakan lahan, hutan dan air, baik langsung maupun tidak langsung yang mempengaruhi ketidakmampuan lahan mendukung kehidupan.
Pemanasan global akibat terus meningkatnya konsentrasi gas rumah kaca di atmosfer mempengaruhi intensitas bencana longsor yang terjadi. Kondisi tersebut sebagai akibat penggunaan bahan bakar yang berlebihan dan pengurangan luas ruang terbuka hijau yang ada, sehingga menyebabkan terjadinya perubahan pola iklim dan cuaca yang ada. Perubahan pola iklim dan curah hujan meningkatkan intensitas curah hujan yang tinggi dalam waktu yang relatif singkat. Intensitas curah hujan yang tinggi di beberapa wilayah dengan kondisi lahan yang kritis menyebabkan terjadinya longsor di beberapa wilayah di Indonesia.

\section{TINJAUAN PUSTAKA}

\section{Pengertian Longsoran dan Bencana Alam}

Bencana alam longsoran tanah yang banyak terjadi di Indonesia merupakan salah satu jenis gerakan massa tanah (soil mass movement) pada lereng-lereng alam. Apabila massa yang bergerak ini didominasi oleh massa tanah dan gerakannya melalui suatu bidang pada lereng, baik berupa bidang miring ataupun lengkung, maka proses pergerakan tersebut disebut sebagai longsoran tanah. Terjadinya bencana 
alam gerakan tanah ataupun longsoran terutama karena gangguan secara alamiah pada kestabilan tanah dan atau batuan penyusun lereng, baik yang bersifat alamiah maupun non alamiah. Gerakan tanah ataupun longsoran akan dikategorikan sebagai bencana apabila terjadi pada daerah yang dihuni oleh manusia atau pada daerah tempat kegiatan manusia. Jadi aspek kehadiran manusia atau terpengaruhnya aktivitas manusia sangat penting dalam menetapkan apakah suatu gerakan tanah atau longsoran dianggap sebagai bencana atau tidak.

Dari uraian di atas terlihat bahwa gerakan massa tanah atau batuan sebenarnya merupakan bagian dari proses evolusi atau perubahan dinamik suatu bentang alam. Proses tersebut merupakan proses alamiah, khususnya proses transportasi atau pergerakan massa penyusun lereng (mass wasting process), yang kemudian diikuti oleh proses pengendapan (sedimentasi) material yang tertransport. Apabila metarial yang bergerak tersebut terendapkan pada lahan dengan gradien hidrolika masih cukup tinggi atau membentuk endapan dengan kemiringan lereng yang cukup curam, maka endapan tersebut masih dapat mengalami gangguan kestabilan sehingga endapan tersebut dapat bergerak lagi menuruni atau keluar lereng sampai akhirnya mencapai posisi yang stabil. Jadi jelaslah bahwa secara evolusi suatu lereng yang tidak stabil karena curam ataupun tersusun oleh tumpukan tanah yang tebal, akan berevolusi menuju kondisi lebih stabil setelah mengalami proses pelapukan, erosi dan transportasi.

\section{Bagian-bagian Longsoran}

Tanda - tanda awal dari longsoran adalah adanya retakan di bagian atas lereng yang relatif tegak lurus arah gerakan. Retakan ini bila tidak segera ditutup, saat hujan akan terisi oleh air yang berakibat selain melunakkan tanah, juga menambah gaya horisontal yang memicu longsoran. Untuk lebih memahami suatu longsoran, maka perlu diketahui bagian-bagian pada geometri suatu longsoran. Pemahaman tentang bagian-bagian geometri longsoran ini juga sangat diperlukan dalam upaya pencegahan dan penanggulangan longsoran. Bagian-bagian longsoran yang diusulkan oleh Cruden dan Varnes (1992) dalam Karnawati (2005), diperlihatkan dalam gambar 1 .

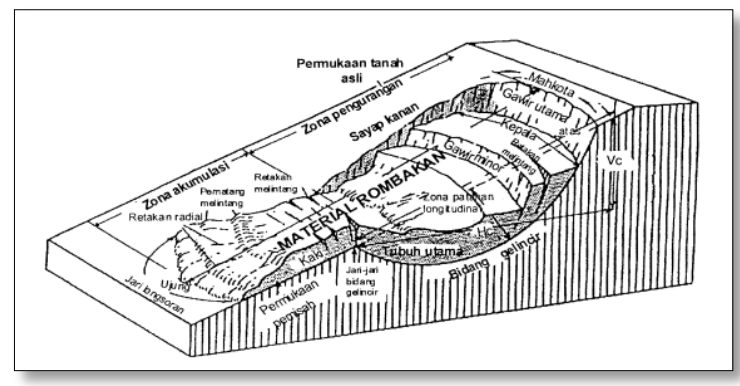

Gambar 1. Bagian-bagian longsoran Cruden dan Varnes (1992) dalam Karnawati (2005)

\section{Penyebab Longsoran Lereng Alam}

Longsoran yang sering terjadi biasanya disebabkan oleh beberapa faktor yang terjadi secara bersamaan. Adapun faktor-faktor penyebab longsoran yang sering terjadi adalah :

- Bertambahnya beban pada lereng seperti bangunan, beban dinamis yang disebabkan tiupan angin pada pohon-pohon dan lain-lain.

- Penggalian atau pemotongan kaki lereng.

Longsoran akibat penggalian kaki lereng dapat mengurangi tekanan overburden, sehingga tanah atau batuan mengembang dan kuat gesernya turun.

- Penggalian yang mempertajam kemiringan lereng.

Banyak kejadian longsoran dipicu oleh penggalian lerang untuk jalan raya, jalan rel dan pembangunan di atas lereng.

- Perubahan posisi muka air secara cepat (rapid drawdown) pada sungai, bendungan, dan lainlain.

- Tekanan lateral yang diakibatkan oleh air terutama air hujan.

Hujan pemicu gerakan tanah adalah hujan yang mempunyai curah tertentu dan berlangsung selama periode waktu tertentu, sehingga air yang jatuh akan berinfiltrasi ke dalam tanah. Air yang berinfiltrasi ke dalam tanah akan berakumulasi di sepanjang bidang longsor akan mereduksi tegangan efektif dan mengurangi kuat geser tanah. Tipe hujan deras hanya akan efektif memicu longsoran pada lereng-lereng yang tanahnya mudah menyerap air (Premchit, 1995; Karnawati, 1996, 1997, dalam Karnawati, 2005), seperti misalnya pada tanah lempung pasiran atau tanah pasir yang besifat permeable. Pada lereng demikian longsoran dapat terjadi pada bulan awal - awal musim hujan. Apabila tanah pembentuk lereng merupakan tanah lempung yang sulit meloloskan air (impermeable), hujan yang deras kurang efektif meresap (berinfiltrasi) ke dalam tanah dan hanya akan menjadi aliran permukaan/limpasan (run off). Jadi bisa disimpulkan bahwa hujan yang tidak deras tetap durasinya lama, lebih efektif memicu terjadinya gerakan tanah / longsor. Hujan dengan durasi lama ini dikenal dengan nama hujan anteseden.

- Penurunan tahanan geser tanah pembentuk lereng akibat kenaikan kadar air, kenaikan tekanan air pori, tekanan rembesan oleh genangan air di dalam tanah, tanah pada lereng mengandung lempung yang mudah mengembang dan lain-lain.

- Getaran atau gempa bumi.

Getaran atau gempa bumi menyebabkan terjadinya liquefaction pada pasir atau lanau longgar yang jenuh air.

\section{Faktor - faktor Penyebab Longsor}

Lokasi-lokasi yang rawan longsor umumnya dipengaruhi oleh kondisi geometri lokasi, pola 
drainase, dan kondisi geologi lokal atau kondisi tanah / batuan (Hardiyatmo, 2007). Berikut ini akan diuraikan hal - hal yang berkaitan dengan faktorfaktor tersebut.

- Lereng di sisi jalan

Lereng bekas galian badan jalan merupakan lokasi yang rawan longsor. Kaki lereng di sepanjang galian sangat mudah tergerus air sehingga menghilangkan dukungan tanah terhadap longsoran.

- Lereng yang terjal

Menurut Karnawati (2005) lereng dengan kemiringan $>400$ sangat rentan terhadap longsor. Lereng terjal yang banyak batuan lepas sangat berbahaya, terutama bagi kendaraan yang melintas di bawahnya.

- Buruknya sistem drainase

Tidak berfungsinya drainase dengan baik akan memicu aliran air kemana-mana. Air akan berusaha mencari tempat yang lebih rendah dan sebagian akan berinfiltarsi kedalam tanah. Air yang mengalir di dalam tanah dapat menjenuhkan dan melunakkan tanah timbunan dan tanah pondasi jalan yang dapat berakibat rusaknya konstruksi. Demikian pula air permukaan (run off) yang tidak mengalir dengan baik ke luar struktur timbunan, akan menjenuhkan tanah atau merembes masuk ke dalam rekahan batuan yang akan mengurangi kestabilan lereng.

- Muka air tanah memotong lereng

Air tanah yang memotong lereng akan menimbulkan munculnya mata air pada daerah ini. Mata air ini diakibatkan oleh terakumulasinya air yang berinfiltrasi ke dalam lereng yang akan melunakkan tanah atau batuan pembentuk lereng.

\section{Gaya - gaya Penyebab Longsor}

Berat sistem tanah yang berpotensi longsor dapat diestimasikan dari hasil penyelidikan tanah pada lereng. Gaya-gaya rembesan oleh aliran air di dalam tanah, merupakan hal yang paling sulit diidentifikasi. Tekanan air yang berkembang dalam lapisan lolos air atau retakan yang terletak di belakang tanah yang berpotensi longsor, dapat juga menimbulkan gaya tambahan yang menyebabkan kelongsoran. Pengaruh gaya gempa pada terjadinya longsoran juga sulit diperkirakan. Variabel utama yang mendefinisikan gaya-gaya yang menyebabkan kelongsoran adalah sudut kemiringan bidang longsor potensial, jika sudutnya lebih besar maka potensi longsor lebih besar. Permukaan bidang longsor ini sangat sulit ditentukan secara tepat dari penyelidikan lokasi.

\section{Gaya - gaya Penahan}

Gaya penahan utama gerakan longsor adalah tahanan geser material di sepanjang bidang longsor. Tahanan geser di sepanjang bidang geser terkait dengan sudut gesek terdrainase (drained friction angle) tanah pada bidang longsor.
Tahanan terhadap longsoran juga dapat tereduksi oleh naiknya tekanan air pada bidang longsor. Kenaikan tekanan air ini mengurangi tahanan gesek, karena gaya normal pada bidang longsor menjadi berkurang.

\section{Prinsip Kestabilan Lereng}

Penyebab terjadinya longsor pada lereng secara mekanik dapat dipahami dengan pendekatan prinsip kestabilan lereng. Dengan prinsip ini akan diketahu gaya-gaya apa saja yang mengontrol kestabilan suatu lereng. Kestabilan pada lereng ditentukan oleh gayagaya yang berusaha melongsorkan (driving forces) tanah atau batuan dan gaya-gaya yang berusaha mempertahankan (resisting forces) tanah atau batuan itu tetap pada posisinya. Besarnya kuat geser tanah atau batuan dikontrol oleh kohesi (c) dan sudut gesek dalam antara partikel-partikel penyusun tanah atau batuan $(\varphi)$. Besarnya nilai kohesi tergantung pada kekuatan ikatan antara atom-atom atau molekulmolekul penyusun partikel-partikel tanah atau batuan ataupun tergantung pada kekuatan sementasi antar partikel-partikel tanah atau batuan. Sudut gesek dalam merupakan nilai yang mengekspresikan kekuatan friksi antara partikel-partikel penyusun tanah atau batuan.

\section{Sistem Drainase Untuk Penanggulangan Longsor}

Yang dimaksud dengan penanggulangan longsoran adalah adalah tindakan yang bersifat pencegah an dan tindakan korektif. Tindakan pencegahan dimaksudkan untuk menghindari kemungkinan terjadinya longsor, sedangkan tindakan korektif dilakukan setelah longsor terjadi. Menurut umur kestabilannya, tindakan korektif dikategorikan menjadi 2 (dua) kelompok, yaitu penanggulangan darurat dan penanggulangan permanen.

1. Penanggulangan Darurat

Penanggulangan darurat adalah tindakan korektif yang sifatnya sementara dan umumnya dilakukan sebelum penanggulangan permanen dilaksanakan. Penanggulangan darurat dapat dilaksanakan dengan tindakan-tindakan sebagai berikut:

- Mencegah masuknya air permukaan ke dalam area longsoran dengan cara membuat saluran terbuka.

- Mengeringkan genangan air yang berada pada bagian atas longsoran.

- Mengalirkan genangan air dan mata air yang tertimbun maupun yang terbuka.

- Menutup rekahan dengan tanah liat.

- Membuat beban kontra (counter weight) pada kaki longsoran, misalnya dengan bronjong ataupun karung yang berisi tanah.

- Pelebaran ke arah tebing.

- Pemotongan bagian kepala longsoran.

\section{Penanggulangan Permanen}

Penanggulangan permanen memerlukan waktu untuk penyelidikan, analisis, dan perencanaan yang 
matang. Metode penanggulangan longsoran dibedakan menjadi 3 (tiga) kategori, yaitu:

a. Mengurangi gaya-gaya yang menimbulkan gerakan tanah dengan cara:

- Mengubah geometri lereng

- Mengendalikan air permukaan

b. Menambah gaya-gaya yang menahan gerakan tanah dengan cara:

- Mengendalikan air rembesan

- Penambatan

- Beban kontra (counter weight)

c. Jika kedua metode di atas tidak dapat mengatasi longsoran yang terjadi maka dilakukan penanggulangan dengan tindakan lain, misalnya:

- Stabilisasi

- Relokasi

- Bangunan silang

- Bangunan bahan ringan

Untuk penanggulangan gerakan tanah atau longsor disesuaikan dengan tipe gerakan, faktor penyebab, dan kemungkinan untuk dapat dikerjakan (work ability). Pemilihan tipe penanggulangan juga harus memperhatikan faktor-faktor yang berkaitan dengan pelaksanaan, yaitu tingkat kepentingan, aspek sosial, dan ketersediaan material di sekitar lokasi longsoran.

lain :

Beberapa tipe penanggulangan longsor antara

1. Mengubah Geometri Lereng

Pengubahan geometri lereng dapat dilakukan dengan pemotongan dan penimbunan (cut and fill). Bagian yang dipotong disesuaikan dengan geometri daerah longsoran, sedangkanpenimbunan dilakukan di kaki lereng. Pemotongan geometri terdiri dari:

- Pemotongan kepala (bagian atas) lereng.

- Pelandaian.

- Penanggaan.

- Pemotongan habis.

- Pengupasan tebing.

- Pengupasan lereng.

2. Mengendalikan Air Permukaan

Mengendalikan air permukaan merupakan langkah awal dari setiap rencana penanggulangan longsoran. Pengendalian air permukaan ini bertujuan untuk mengurangi berat massa tanah yang bergerak dan menambah kekuatan material pembentuk lereng.

Dua hal yang harus diperhatikan adalah air permukaan yang akan mengalir pada permukaan lereng dan yang akan meresap ke dalam tanah. Air permukaan harus dicegah agar tidak mengalir menuju area longsoran, sedangkan mata air, rembesan, dan genangan di area longsoran harus dialirkan ke luar.

Mengendalikan air permukaan dapat dilakukan dengan cara-cara sebagai berikut:

- Menanam Tumbuhan

- Tata Salir

- Menutup Rekahan

- Perbikan Permukaan Lereng
3. Mengendalikan Air Rembesan (Drainase Bawah Permukaan)

Mengeringkan atau menurunkan muka air tanah dengan mengendalikan air tanah merupakan usaha yang sulit dan membutuhkan penyelidikan yang cermat.

Metode pengendalian air rembesan yang dapat digunakan adalah sebagai berikut:

- Sumur Dalam

- Penyalir Tegak (Saluran Tegak)

- Penyalir Mendatar (saluran Mendatar)

- Pelantar

- Sumur Pelega

- Penyalir Parit Pencegat (Saluran Pemotong)

- Penyalir Liput

- Elektro Osmosis

4. Penambatan

Metode penambatan ini terbagi dalam 2 (dua) kategori, yaitu penambatan tanah dan penambatan batuan.

Penambatan tanah terdiri dari:

- Tembok penahan

- Sumuran

- Tiang pancang

- Turap baja

- Bored pile

Sedangkan penambatan batuan terdiri dari:

- Tumpuan beton

- Baut batuan

- Pengikat beton

- Jangkar kabel

- Jala kawat

- Tembok penahan batu

- Beton semprot

- Dinding tipis

5. Tindakan Lain

Tindakan ini diambil bila penanggulangan dengan metode-metode yang telah diuraikan diatas tidak bisa diterapkan. Tindakan ini meliputi penggunaan bahan ringan, penggantian material, stabilisasi, bangunan silang, dan relokasi.

\section{METODOLOGI PENELITIAN}

\section{Lokasi Study}

Study Kasus ini di wilayah Sungai Cikapundung. Sungai Cikapundung adalah sub DAS Citarum yang memiliki panjang total 28 kilometer. Dari panjang total $28 \mathrm{~km}$, sekitar 15,5 km aliran sungai melintasi Kota Bandung. Topografi Kota Bandung adalah berbukit di bagian utara dan melandai di bagian selatan dengan elevasi antara $750-1000 \mathrm{~m}$ di atas permukaan laut. Sungai Cikapundung Kabupaten Babakan Siliwangi dan Sungai Cikapundung adalah salah satu sungai yang membelah Kota Bandung melewati 9 kecamatan yang mencakup 13 kelurahan. 


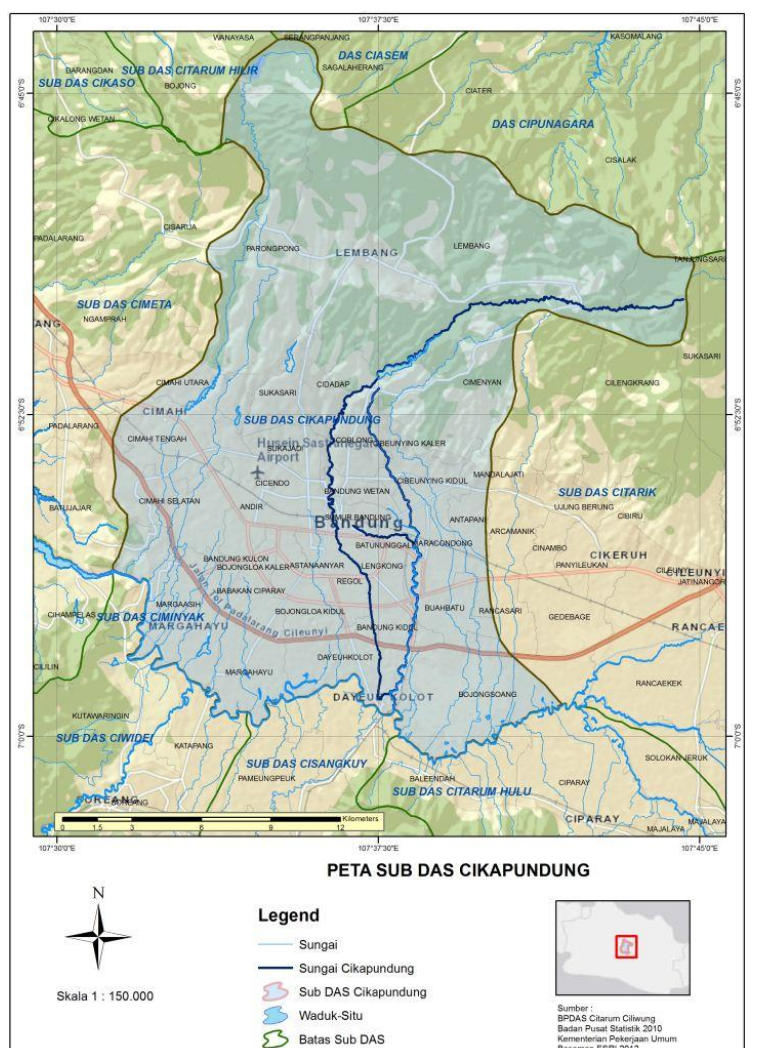

Gambar 2. Peta Sub DAS Cikapundung

BAPPEDA Kota Bandung menyebutkan bahwa sehari-harinya sungai ini memiliki potensi sebagai penyedia air baku untuk wilayah Kota Bandung dan sekitarnya selain sebagai drainase utama kota.

Sungai Cikapundung memiliki fungsi dan peran yang sangat penting bagi perkembangan Kota Bandung, karena sungai ini berfungsi sebagai sumber air baku bagi Kota Bandung. Kawasan Sungai Cikapundung dalam Raperda Rencana Tata Ruang Wilayah (RTRW) Kota Bandung Tahun 2011-2030, ditetapkan sebagai salah satu Kawasan Strategis Kota (KSK) yang mempunyai nilai strategis dari sudut kepentingan fungsi daya dukung lingkungan hidup, (BAPPEDA Kota Bandung, 2011). Sungai Cikapundung juga memiliki potensi antara lain berpotensi menjadi area pariwisata, diantaranya budaya tradisional kukuyaan yaitu berpotensi menjadi olahraga arung jeram.

\section{PEMBAHASAN}

Dari penelitian yang dilakukan di beberapa tempat yang rawan longsor disebabkan karena oleh semakin banyaknya pemukiman penduduk yang menghuni di sepanjang garis sempadan sungai.

Pada saat kegiatan penelitian dilakukan ditemukan sejumlah bangunan yang berada di garis sempadan sungai dengan jarak 0-3 m yang dimanfaatkan untuk pemukiman. Pemukiman yang berada tepat di bibir sungai ini menyebabkan banyaknya masyarakat yang membuang sampah langsung ke sungai dan menyebabkan sampah bertumpuk dan bersendimentasi. Sungai yang bersendimen akan menjadi lebih landai sering meluap dan berpotensi banjir.

Beberapa upaya yang dapat dilakukan dengan rekayasa teknik sipil antara lain berupa pengurugan/penutupan rekahan, reshaping lereng, bronjong kawat, perbaikan drainase, baik perbaikan drainase permukaan seperti saluran pembuangan air maupun drainase bawah tanah.

Pendekatan pengendalian tanah longsor diupayakan agar air tidak terlalu banyak masuk ke dalam tanah yang bisa menjenuhi ruang antara ruang lapisan kedap air dan lapisan tanah.

Untuk menjaga DAS Sungai Cikapundung dari pengaruh kelongsoran yang sering terjadi di area tikungan DAS dilakukan penanggulangan kelongsoran dengan penanggulangan permanen seperti kegiatan Restorasi Sungai Cikapundung Babakan Siliwangi.
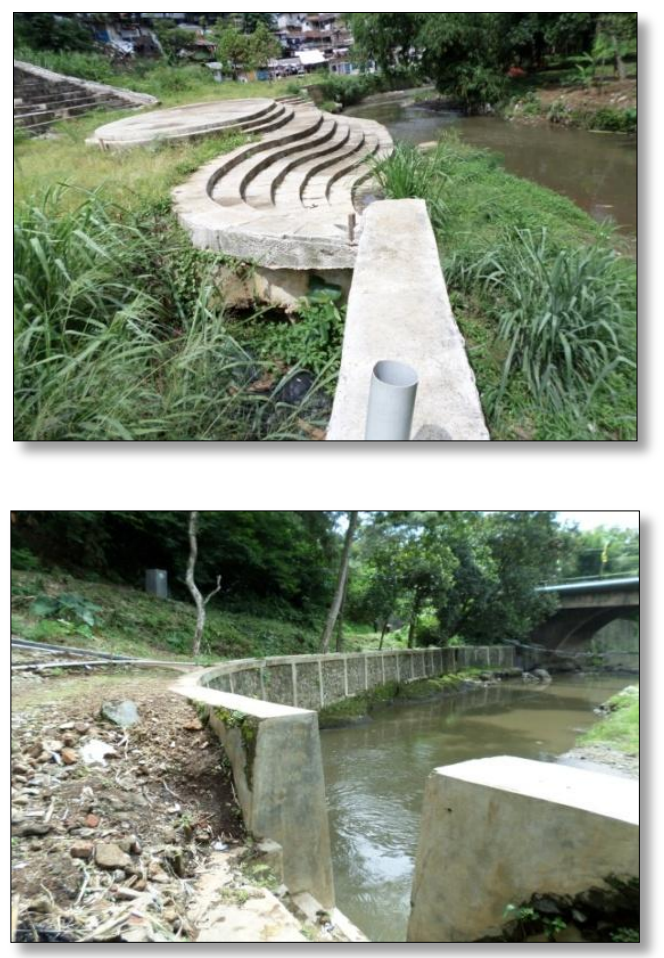

Gambar 3. Tembok Penahan Tanah (Retaining Wall) Restorasi Sungai Cikapundung

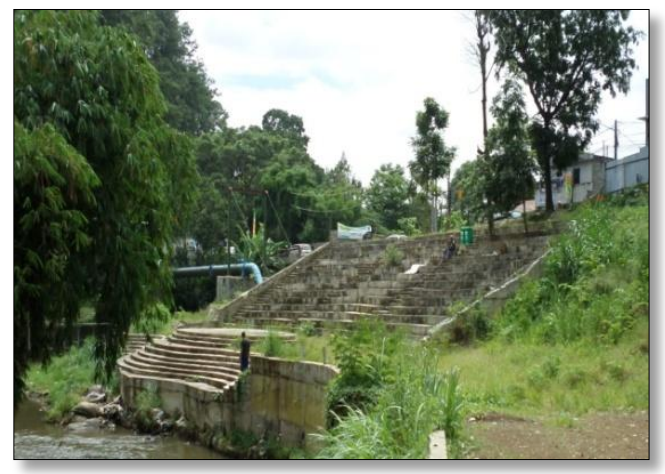




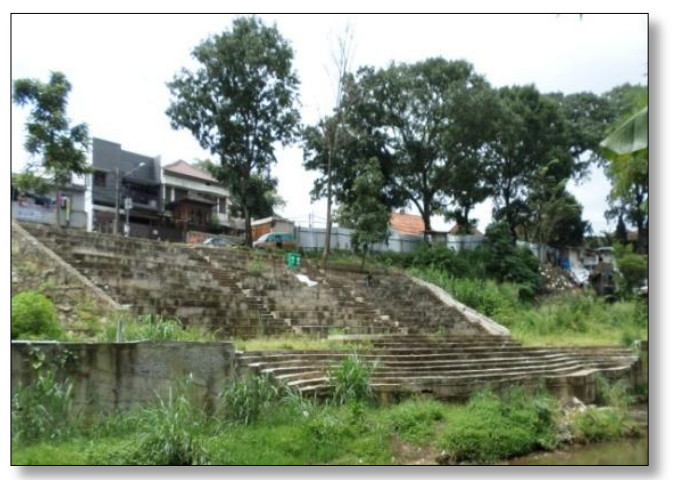

Gambar 4. Tribun Lereng Beton Restorasi Sungai Cikapundung

Dari gambar - gambar pemantauan lokasi di atas didapat kontruksi tembok penahan tanah dan konstruksi kestabilan lereng DAS Sungai Cikapundung yang berfungsi sebagai Ruang Terbuka Hijau (RTH). Untuk mencegah terjadinya kelongsoran pada konstruksi tersebut, maka penanggulangan longsor dipilih penanggulangan permanen dengan tipe penanggulangan longsor Mengendalikan Air Rembesan (Drainase Bawah Permukaan) antara lain :

a. Sumur Dalam

Digunakan untuk menanggulangi longsoran yang bidang longsor relatif dalam dan efektif digunakan pada daerah longsoran yang bermaterial lulus air dan bisa dimanfaatkan air sumur untuk kepentingan umum dikarenakan cara ini dinilai cukup mahal karena harus melakukan pemompaan secara terus menerus.

\section{b. Penyalir Tegak (Saluran Tegak)}

Metode ini dilakukan dengan cara mengalirkan air tanah sementara ke lapisan lulus air dibawahnya, sehingga menurunkan tekanan hidrostatik. Efektifitas dari metode ini tergantung pada kondisi air tanah dan perlapisannya.

\section{c. Penyalir Mendatar (Saluran Mendatar)}

Penyalir mendatar dibuat untuk mengalirkan air atau menurunkan muka air tanah pada daerah longsoran. Metode ini dapat digunakan pada longsoran besar yang bidang longsornya dalam dengan membuat lubang setengah mendatar hingga mencapai sumber airnya. Air dialirkan melalui pipa dengan diameter $5 \mathrm{~cm}$ atau lebih yang berlubanglubang pada dindingnya.

Penempatan pipa penyalir tergantung pada jenis material yang akan diturunkan muka airtanahnya. Untuk material berbutir halus jarak antar pipa 3-8 meter, sedangkan untuk material kasar berjarak 8-15 meter. Efektifitas cara ini tergantung dari permeabilitas tanah yang mempengaruhi banyaknya air yang bisa dialirkan keluar. Metode ini dipasang pada tembok penahan tanah dan pada tribun kestabilan lereng.

\section{d. Pelantar}

Pelantar sangat efektif untuk menurunkan muka air tanah di daerah longsoran yang besar, tapi pengerjaannya sangat sulit dan mahal. Cara ini lebih banyak dipakai pada lapisan batu, karena umumnya memerlukan penyangga yang lebih sedikit dibandingkan bila dilakukan pada tanah. Agar berfungsi maksimal, pelantar digali di bawah bidang longsor. Kemudian dari atas dibuat lubang yang berhubungan dengan pelantar untuk mempercepat aliran air dalam material yang longsor.

\section{e. Penyalir Parit Pencegat (Saluran Pemotong)}

Penyalir parit pencegat dibuat untuk memotong aliran air tanah yang masuk ke dalam longsoran. Parit ini dibuat di bagian atas mahkota longsoran sampai ke lapisan kedap air, sehingga aliran air tanah tercegat oleh parit tersebut. Pada dasar galian dipasang pipa dengan dinding berlubang untuk mengalirkan air tanah. Pipa ini kemudian ditimbun dengan material yang bisa berfungsi sebagai penyalir filter. Cara ini dapat dilakukan bila kedalaman lapisan kedap air tidak lebih dari 5 meter. Efektifitas cara ini tergantung pada kondisi air tanah dan perlapisannya.metode ini diterapkan pada bagian atas sepanjang tribun kestabilan lereng.

\section{f. Geotekstil}

Geotekstil adalah teknik pelapisan tanah untuk mencegah longsor dan ambles. Untuk itu, digunakan lembar plastik atau polimer dari jenis poliester, polipropilen, atau polietilen. Lapisan plastik ini berfungsi mencegah kebocoran, mengalirkan air yang merembes ke dinding, dan mencegah kebocoran.

Teknik pelapisan yang diperkenalkan Inggris tahun 1960-an ini kemudian dikembangkan Jepang, terutama untuk meningkatkan kekuatan bahan. "Bila yang lama hanya dapat menahan beban 1-2 ton, geotekstil yang baru dapat tahan sampai pembebanan 100 ton.

Dari faktor biaya, pelapisan dengan geotekstil 40 persen lebih murah dibandingkan dengan beton. Masa pengerjaannya dapat dua kali lebih cepat. Penggunaan polimer dapat mempertahankan bentuk alami sehingga tanggul di tepi sungai masih dapat ditanami rumput setelah pelapisan. "Ini berbeda dengan tanggul beton yang keberadaannya menentang alam.

Metode ini dilakukan pada di bawah tribun kestabilan lereng untuk memperkuat kestabilan kontruksi tersebut.

\section{g. Soil Bioengineering}

Soil Bioengineering adalah teknologi yang menggunakan bahan dari tanaman hidup dan bagian dari tanaman, untuk mengatasi persoalan-persoalan mengenai alam lingkungan seperti erosi permukaan tanah dan erosi lereng sungai. Dalam sistem soil bioengineering, tanaman berperan sebagai komponen 
struktural yang utama, tidak hanya sebagai bagian dari estetika lansekap.

Hal yang perlu dilakukan sebelum pelaksanaan metode soil bioengineering adalah pemilihan jenis tanaman dan persiapan lahan. Banyak jenis tanaman yang dapat digunakan dalam metode soil bioengineering, namun tidak semua jenis tanaman cocok untuk digunakan. Jenis tanaman yang cocok untuk digunakan adalah jenis tanaman yang mempunyai karakteristik tumbuh dengan cepat dan berakar cukup dalam dan banyak. Jenis tanaman yang dapat digunakan untuk menjaga stabilitas lereng dan erosi permukaan meliputi rerumputan, palawija, semak-semak, dan pepohonan. Dan untuk jenis tanaman yang akan diterapkan pada restorasi sungai adalah rumput - rumputan, semak - semak dan pohon - pohon.

\section{KESIMPULAN}

Secara umum penanggulangan longsor pada Restorasi Sungai Cikapundung disebabkan oleh beberapa faktor diantaranya adalah air hujan yang berinfiltrasi ke dalam pori-pori tanah yang lolos air yang melunakkan tanah sehingga tanah kehilangan kapasitas dukungnya, selain itu buruknya sistem drainase permukaan di jalan raya yang menyebabkan erosi yang terus menerus menggerus lereng sempadan sungai. Banyak saluran-saluran permukaan yang sudah tidak berfungsi lagi akibat tertutupnya saluran oleh material yang terbawa oleh air hujan. Air hujan berusaha mencari jalannya sendiri sehingga banyak yang terkonsentrasi dan membentuk genangan-genangan di sepanjang permukaan sempadan Sungai.

\section{DAFTAR PUSTAKA}

1. Achmad, F., 2010, Tinjauan Longsoran pada Ruas Jalan Akses - Pelabuhan Gorontalo, Prosiding Simposium Nasional XIII FSTPT, Universitas Katolik Soegijapranata, Semarang, hal $1-10$

2. Aliu, S. W., 2010, Tinjauan Debit Rancangan Kanal Tamalate, Tugas Akhir D3 Jurusan Teknik Sipil Fakultas Teknik UNG (tidak dipublikasikan).

3. Cornforth, D. H., 2005, Landslides in Practice Investigation, Analysis, and Remedial/ Preventative Options in Soils, John Wiley and Sons, Inc., Hoboken, New Jersey.

4. Departemen Permukiman dan Prasarana Wilayah Bidang Pelayanan IPTEK Puslitbang Prasarana Transportasi Balitbang, 2004, Advis Teknik Longsoran dan Penggunaan Geosintetik untuk Penanganan Longsoran Studi Kasus Jalan Akses Pelabuhan, P3JJ, Gorontalo.

5. Hardiyatmo, H. C., 2006, Penanganan Tanah Longsor dan Erosi, Gadjah Mada University Press, Yogyakarta.

6. Hardiyatmo, H. C., 2007, Pemeliharaan Jalan Raya Perkerasan, Drainase, Longsoran, Gadjah Mada University Press, Yogyakarta

7. Ir. Desiana Vidayanti. MT, Pusat Pengembangan Bahan Ajar - Program Studi Teknik Sipil Fakultas Teknik Sipil dan Perencanaan Universitas Mercu Buana

8. Karnawati, D., 2005, Geologi Umum dan Teknik, Program Studi S2 Teknik Sipil UGM, Yogyakarta

9. R. Andre Sagitha, Ferry Sentio Jaya, Daniel Hartanto Universitas Katolik Soegijapranata Semarang.

10. Rahardjo, P. P., 2002, Risiko Geoteknik dan Investigasi Forensik Pada Longsoran, Prosiding Seminar Nasional Slope2002, HMJ-Teknik Sipil Universitas Parahyangan, Bandung, hal. 197-203.

11. Suryolelono, K. B., 2003, Bencana Alam Tanah Longsor, Perspektif Ilmu Geoteknik, Pidato Pengukuhan Jabatan Guru Besar pada Fakultas Teknik Universitas Gadjah Mada, Yogyakarta (tidak dipublikasikan). 